\title{
Nutritional profile of schoolchildren from different socio-economic levels in Santiago, Chile
}

\author{
Yessica Liberona ${ }^{1}$, Oscar Castillo', Valerie Engler ${ }^{1}$, Luis Villarroel ${ }^{2}$ and \\ Jaime Rozowski ${ }^{1, *}$ \\ ${ }^{1}$ Nutritional Intervention Unit, Department of Nutrition, Diabetes and Metabolism, Pontificia Universidad Católica \\ de Chile, Edificio de Gastroenterología - $4^{\circ}$ piso, Lira 40, Santiago, Chile: ${ }^{2}$ Department of Public Health Faculty \\ of Medicine, Pontificia Universidad Católica de Chile, Santiago, Chile
}

Submitted 14 September 2009: Accepted 22 April 2010: First published online 29 June 2010

\begin{abstract}
Objective: To assess the nutritional status, food intake and physical activity patterns in schoolchildren attending 5 th and 6th grade in basic schools from different socio-economic levels in the metropolitan region of Santiago.

Design: Cross-sectional study in children 5th and 6th grade of eighteen basic schools in the metropolitan region of Santiago.

Setting: Boys and girls aged 9-12 years from basic schools were evaluated in terms of physical capacity. An anthropometric evaluation was also performed which included weight, height and triceps and subscapular skinfold thicknesses. Food intake was evaluated by a $24 \mathrm{~h}$ recall, socio-economic level by the ESOMAR method and physical activity by a questionnaire.

Subjects: Boys and girls aged 9-12 years ( $n$ 1732).

Results: The average prevalence of overweight and obesity was $40 \%$, with the highest prevalence in males and those from lower socio-economic level. A majority (64\%) of the children had a low level of physical activity. A higher intake of fat and protein and a higher intake of carbohydrate were found in the higher and lower socio-economic levels, respectively. Both males and females showed adequacy greater than $75 \%$ in macronutrient intake except for fibre, with both groups showing a deficit in the consumption of fruits, vegetables, legumes, fish and milk products according to Chilean recommendations.

Conclusions: A high prevalence of malnutrition by excess was observed in both sexes and a better eating and physical activity pattern was seen in children from higher socio-economic level.
\end{abstract}

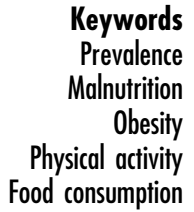

The prevalence of obesity has been increasing steadily in both the developed and the developing world ${ }^{(1,2)}$. In the latter, the increase in obesity in most countries has been concomitant with a decrease in undernutrition and mortality from infection ${ }^{(3)}$. Several studies have dealt with the burden of obesity in national health systems. Obesity is a risk factor for diabetes, hypertension and CVD, and has been shown to impose a heavy burden in terms of disability-adjusted life years lost to the disease ${ }^{(4)}$.

In Chile, malnutrition has all but disappeared. During the last four decades, infant mortality dropped from $150 / 1000$ live births in 1970 to less than $7 / 1000$ in $2007^{(3)}$. The causes for this decline are multiple, including improvement in sanitation, a decrease in fertility, the implementation of feeding programmes for women and children, and others. The nutrition survey conducted by the Interdepartmental Committee on Nutrition and National Defence (ICNND) in 1960 showed that $8.3 \%$ of children aged 15-24 years were obese (weight/height index $>120 \%)^{(5)}$. Data from the Ministry of Education, which measures weight and height of all children entering basic school (age 6-7 years) in the country, show that their obesity prevalence (BMI $>95$ th percentile) has trebled in the last 20 years, rising from $5 \cdot 5 \%$ to $22 \cdot 2 \%$ between 1988 and 2007, respectively ${ }^{(6)}$.

Data on the prevalence of obesity in older Chilean children are scarce. The National Health Survey held in 2003 showed that $27 \%$ of people aged 17 years and older were obese (BMI $>30 \mathrm{~kg} / \mathrm{m}^{2}$ ) and $38 \%$ were overweight $\left(\mathrm{BMI}=25-30 \mathrm{~kg} / \mathrm{m}^{2}\right)$. Children younger than 17 years were not studied ${ }^{(7)}$.

Data on food intake and physical activity (PA) in children are also limited, the majority of studies being done on children of low socio-economic level (SEL) and with qualitative data on food intake. Olivares et al. assessed food intake by means of a quantitative food register in 1700 Chilean children aged 8-13 years. Only five food items were evaluated, showing a high intake of snacks 
and sweetened beverages and a low intake of dairy products, fruits and vegetables. Children spent at least $3 \mathrm{~h}$ daily watching television during weekdays and double that amount during the weekend ${ }^{(8,9)}$.

In terms of studies of food consumption in Chile, the first nutrition survey performed at the national level was the ICNND survey in 1960. After that, a national survey was performed in 1974 but it was never published in its entirety. Most information on food consumption in older children comes from relatively small studies that usually are not representative of the population.

Therefore the purpose of the present work was to study the prevalence of overweight and obesity in Chilean children aged 9-12 years from schools from the metropolitan region of Santiago and to correlate this prevalence to SEL, food intake and PA.

\section{Materials and methods}

The survey sample consisted originally of 1800 children from the 5th and 6th grade attending public and private schools representative of the population of the metropolitan region of Santiago, Chile. The data were collected from March to June 2007. Sixty-eight children were not measured since they did not comply with the inclusion criteria (mainly due to failure of their parents to sign the informed consent), so the final sample size was 1732 children aged 9-12 years of whom $51 \cdot 6 \%$ were boys. Schools were selected by the School Vulnerability Index (SVI), which ranks the institutions according to $\mathrm{SEL}^{(10)}$. Inclusion criteria were children of both sexes, attending the 5th and 6th grade in basic schools that covered the range of SEL (private, subsidized and municipal schools), who agreed to be assessed and whose parents signed an informed consent. Children who presented with any condition that could alter anthropometric measurements or food intake were excluded from the study. The study was approved by the Human Investigation Committee of the Catholic University of Chile.

\section{Nutritional status}

Nutritional status was determined by BMI adjusted for age using the Centers for Disease Control and Prevention/ National Center for Health Statistics (2000) growth charts. Cut-off points were: underweight, BMI $<10$ th percentile; normal, BMI $\geq 10$ th to $<85$ th percentile; overweight, $\mathrm{BMI} \geq$ 85 th to $<95$ th percentile; obese, $\mathrm{BMI} \geq 95$ th percentile ${ }^{(11)}$.

\footnotetext{
Anthropometry

Weight and height were measured with a DETECTO model 2391 scale (Webb City, MO, USA) with an attached stadiometer (precision $100 \mathrm{~g}$ and $0 \cdot 1 \mathrm{~cm}$, respectively). Skinfold thickness was measured with a Harpenden calliper (West Sussex, UK), range $0-100 \mathrm{~mm}$, which exerts a constant pressure of $10 \mathrm{~g} / \mathrm{mm}^{2}$. Triceps skinfold thickness was determined in the middle point between the acromion and
}

the olecranon in the relaxed forearm. Subscapular skinfold thickness was measured under and inside the scapula with relaxed arm and shoulder. All measurements were made by a nutritionist (Y.L.) certified by the International Society for the Advancement of Kinathropometry.

Fat mass was calculated by the Slaughter formula which considers age, triceps and subscapular skinfold thicknesses ${ }^{(12)}$. This formula was chosen since it represents the best correlation with measurements obtained by dual-energy X-ray absorptiometry, considered the 'gold standard' to measure body fat mass ${ }^{(13)}$.

\section{Food intake}

Food consumption was measured by means of a $24 \mathrm{~h}$ recall that was quantified and analysed in the Food Processor 7.9 software program (ESHA Research, Salem, OR, USA), which has previously been validated for Chilean foods ${ }^{(14)}$. All interviews were performed by the same nutritionist in a personal meeting with the children. Energy intake was compared with the FAO/WHO/United Nations University recommendations to assess adequacy ${ }^{(15)}$. Macro- and micronutrient intakes were compared with the recommendations of the Food and Nutrition Board, Institute of Medicine ${ }^{(16-19)}$. Food intake was compared with the recommendation of the Chilean Ministry of Health ${ }^{(3)}$.

\section{Physical activity}

For determination of the level of PA, a questionnaire previously validated by Burrows et al. was used ${ }^{(20)}$. This survey is composed of five activities (recumbent, seated, walking, playing outdoors, sports) which translate into a PA score of $0-10$ points to classify levels of activity as bad (score $=0-3$ ), regular (score $=4-6$ ) or good (score $=7-10)$ according to the hours spent in different activities. The PA score was compared with a $3 \mathrm{~d}$ accelerometer measurement in seventy-seven of ninety-three children (thirty-five obese and forty-two non-obese). Accelerometry was significantly associated with PA score $(P=0 \cdot 008)$, playing outdoors $(P=0.0009)$ and practising sports $(P=0 \cdot 003)$.

\section{Socio-economic level}

The schools were classified according to the SVI, calculated by the Chilean National Organization for School Help and Fellowships (JUNAEB), which measures the SEL of each school as an institution. In addition to the SVI we applied the European Survey (ESOMAR) socio-economic scale to each child, which is restricted to activity and education of the breadwinner ${ }^{(21)}$. This instrument classifies SEL as very high (a), high (b), middle-high (ca), middle (cb), middle-low (d) and low (e). The results are shown as a+b, ca, cb, d and d+e.

\section{Statistical analyses}

Continuous variables are shown as mean and standard deviation, while categorical variables as the number of cases and percentage. Student's $t$ test and the $\chi^{2}$ test were 
performed for comparison of mean and proportions, respectively. For the comparison of more than two variables, one-way ANOVA and the $t$ test for multiple comparisons with Hochberg correction were performed. Significant $P$ value was set at $0 \cdot 05$. Data processing and statistical analyses were done with the SPSS statistical software package version $15 \cdot 0$ (SPSS Inc., Chicago, IL, USA).

\section{Results}

A general description of the children in the study is shown in Table 1. There were no significant differences between males and females except in height and percentage fat mass. Based on the BMI cut-off points shown above, $59 \%$ of the children were classified as normal weight, 22\% as overweight, $17 \%$ as obese and $2 \%$ as underweight. When children were separated by gender, boys were significantly more obese than girls $(21 \cdot 2 \% v .12 \cdot 4 \%$, respectively; Fig. 1$)$.

When classified by the ESOMAR socio-economic scale, $17 \cdot 6 \%$ of the sample belonged to very high and high SEL $(\mathrm{a}+\mathrm{b}), 14 \cdot 3 \%$ to middle-high SEL (ca), 34.6\% to medium SEL (cb) and $33.5 \%$ belonged to low or very low SEL $(\mathrm{d}+\mathrm{e})$. Figure 2 shows the nutritional status of the children in relation to SEL. Obesity was more prevalent among those with lower SEL (cb and $d+e$ ) while overweight was more prevalent in the middle-high SEL group (ca). The group with highest SEL (a) showed a 76.6\% prevalence of normal weight. The prevalence of underweight, although low in general, was double in the groups with lower SEL compared with those of higher SEL.

The PA score was very low for all populations studied. Figure 3 shows that $65 \cdot 4 \%$ of the total population was sedentary, $33.9 \%$ had regular PA and only $0.7 \%$ showed a good level of PA, with no significant differences between boys and girls. Children from high SEL were significantly more active than children from lower SEL. No significant differences were observed in PA related to nutritional status (data not shown).

Table 2 shows the consumption of energy and macronutrients according to PA. Higher PA score was significantly associated with a higher intake of energy, protein, total fat and MUFA. High PA also correlated with a higher intake

Table 1 General characteristics of the sample: children aged 9-12 years ( $n$ 1732), metropolitan region of Santiago, Chile, MarchJune 2007

\begin{tabular}{lcclll}
\hline & \multicolumn{2}{c}{ Boys $(n$ 894) } & & \multicolumn{2}{c}{ Girls $(n$ 838) } \\
\cline { 2 - 3 } \cline { 6 - 6 } & Mean & SD & & Mean & SD \\
\hline Age (years) & $11 \cdot 2$ & $0 \cdot 7$ & & $11 \cdot 2$ & $0 \cdot 7$ \\
Weight $(\mathrm{kg})$ & $43 \cdot 2$ & $9 \cdot 4$ & & $43 \cdot 4$ & $9 \cdot 9$ \\
Height $(\mathrm{m})$ & $1 \cdot 45^{\star}$ & $0 \cdot 10$ & & $1 \cdot 46$ & $0 \cdot 10$ \\
BMI $\left(\mathrm{kg} / \mathrm{m}^{2}\right)$ & $20 \cdot 4$ & $3 \cdot 5$ & & $20 \cdot 2$ & $3 \cdot 5$ \\
Body fat $(\%)$ & $21 \cdot 5^{\star}$ & $6 \cdot 4$ & & $23 \cdot 1$ & $6 \cdot 5$ \\
\hline
\end{tabular}

Mean values were significantly different from those of girls (Student $t$ test): ${ }^{*} P<0.005$. of $\mathrm{Ca}, \mathrm{P}, \mathrm{K}, \mathrm{Zn}$, vitamin $\mathrm{A}$, niacin, vitamin $\mathrm{B}_{6}$, vitamin $\mathrm{B}_{12}$ and vitamin $\mathrm{D}$ (data not shown).

Table 3 shows the relationship between energy and macronutrient intake and SEL. Energy intake was higher in both extremes of the SEL classification, while the consumption of protein, total fat, MUFA, PUFA, Ca, Mg, P, K and $\mathrm{Zn}$ was significantly higher in the high SEL group compared with the other groups. The lowest SEL group had a higher intake of carbohydrate, Fe, Se and Na. Paradoxically, obese children reported lower energy intake than all the other categories. Obese children also reported decreased intakes of protein, carbohydrate, fibre, total fat, SFA, MUFA, PUFA and cholesterol (data not shown).

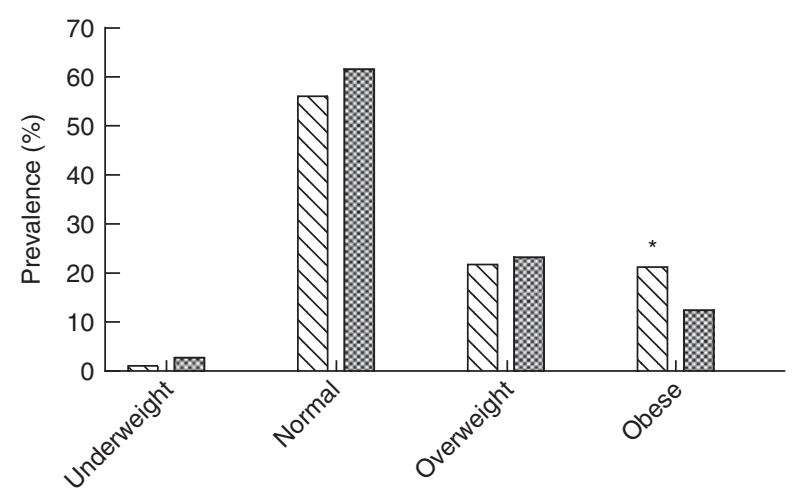

Fig. 1 Nutritional status according to sex among boys $(\mathbb{\nabla})$ and girls (清) aged 9-12 years ( $n$ 1732), metropolitan region of Santiago, Chile, March-June 2007. Nutritional status determined according to BMI-for-age using the Centers for Disease Control and Prevention/National Center for Health Statistics (2000) growth charts, cut-off points were: underweight, $<10$ th percentile; normal weight, $\geq 10$ th to $<85$ th percentile, overweight, $\geq 85$ th to $<95$ th percentile; obese, $\geq 95$ th percentile. Prevalence was significantly different from that in girls: ${ }^{\star} P<0.05$

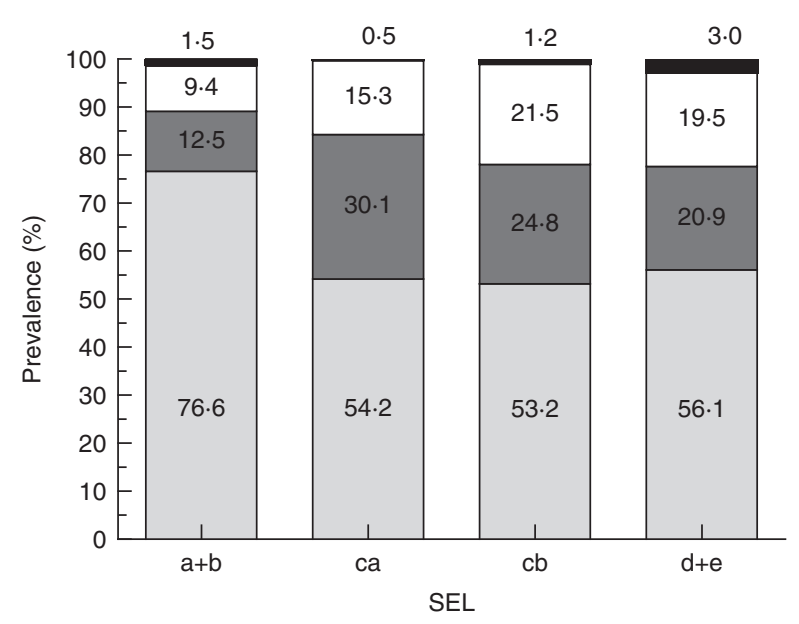

Fig. 2 Nutritional status ( $\square$, underweight; $\square$, normal weight; $\square$, overweight; $\square$, obese) according to socio-economic level (SEL; $\mathrm{a}+\mathrm{b}$, very high and high; ca, middle-high; $\mathrm{cb}$, middle; $\mathrm{d}+\mathrm{e}$, middle-low and low) among children aged 9-12 years ( $n$ 1732), metropolitan region of Santiago, Chile, March-June 2007 
Macro- and micronutrient consumption correlated with the intake of specific foods (Table 4). Poorer groups consumed significantly more bread, sugar and legumes

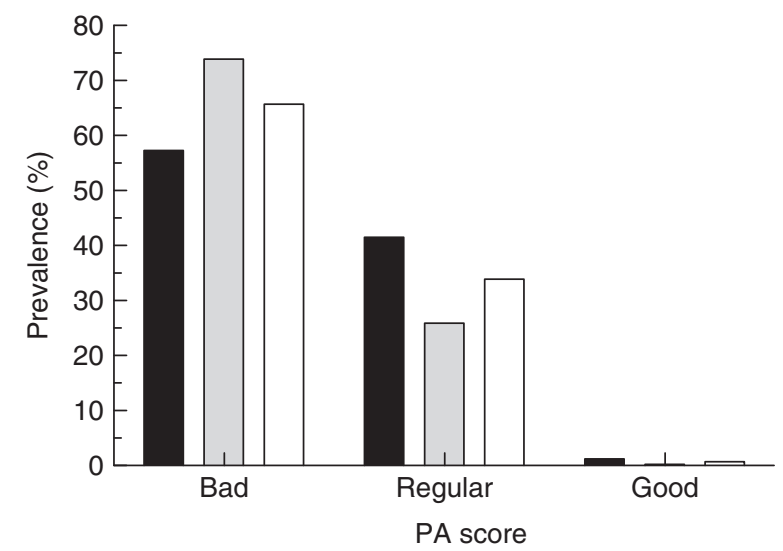

Fig. 3 Level of physical activity (PA) according to sex ( $\square$, boys; $\square$, girls) and in the total population ( $\square$ ) among children aged 9-12 years (n 1732), metropolitan region of Santiago, Chile, MarchJune 2007. PA score derived from a survey of five activities (recumbent, seated, walking, playing outdoors, sports), translating into a PA score of $0-10$ points, to classify levels of activity as bad (score $=0-3$ ), regular (score $=4-6$ ) or good (score $=7-10$ ) according to the hours spent in the different activities than the richer groups, and significantly less of other foods. No relationship was found between SEL and consumption of sweetened beverages, candy and fish. Overweight and obese children reported less consumption of dairy products, cereals, bread and fat than children of normal weight $(P<0 \cdot 001$; data not shown).

The adequacy of food intake in boys and girls according to the recommendations of the Chilean Ministry of Health ${ }^{(22)}$ is shown in Tables 5 and 6. A low adequacy of consumption of legumes, fruits, vegetables, fish and dairy products was found in all groups.

\section{Discussion}

The prevalence of obesity found in the present study was higher in lower SEL groups while overweight was more prevalent in higher SEL groups (middle-high and high $\mathrm{SEL}$ ). In the higher income groups normal weight was found in $80 \%$ of children, while in the lower income groups only $56 \%$ had normal weight. The relationship between SEL and obesity has been reviewed by Lioret et $a{ }^{(23)}$. In Chilean schoolchildren aged 8-13 years, Olivares et al. reported that those with better SEL had less

Table 2 Energy and micronutrient consumption according to level of physical activity (PA) among children aged 9-12 years ( $n$ 1732), metropolitan region of Santiago, Chile, March-June 2007

\begin{tabular}{|c|c|c|c|c|c|c|c|}
\hline & \multicolumn{6}{|c|}{ PA score } & \multirow[b]{3}{*}{$P+$} \\
\hline & \multicolumn{2}{|c|}{$\begin{array}{c}\text { Bad (0-3) } \\
(n 1021)\end{array}$} & \multicolumn{2}{|c|}{$\begin{array}{l}\text { Regular (4-6) } \\
\quad(n 511)\end{array}$} & \multicolumn{2}{|c|}{$\begin{array}{c}\text { Good }(7+) \\
\quad(n 11)\end{array}$} & \\
\hline & Mean & SD & Mean & $\mathrm{SD}$ & Mean & SD & \\
\hline Energy (kJ) & 7950 & 2629 & 8281 & 2981 & 9684 & 3324 & 0.01 \\
\hline Protein $(\mathrm{g})$ & $65 \cdot 6^{\mathrm{a}}$ & $22 \cdot 6$ & $70 \cdot 8^{b}$ & $27 \cdot 1$ & $82 \cdot 0^{\mathrm{b}}$ & $24 \cdot 2$ & 0.001 \\
\hline Carbohydrate (g) & $283 \cdot 1$ & $96 \cdot 5$ & $293 \cdot 4$ & $111 \cdot 8$ & $329 \cdot 7$ & $112 \cdot 5$ & 0.07 \\
\hline Fibre $(\mathrm{g})$ & $17 \cdot 5$ & $9 \cdot 9$ & $17 \cdot 2$ & $9 \cdot 3$ & $17 \cdot 6$ & 8.9 & 0.85 \\
\hline Total fat (g) & $57 \cdot 1$ & $26 \cdot 8$ & $59 \cdot 1$ & $28 \cdot 1$ & $75 \cdot 1$ & $39 \cdot 5$ & 0.05 \\
\hline SFA $(g)$ & $19 \cdot 1$ & $9 \cdot 9$ & $19 \cdot 8$ & $9 \cdot 9$ & $22 \cdot 4$ & $8 \cdot 6$ & 0.29 \\
\hline MUFA (g) & $18 \cdot 5$ & $9 \cdot 0$ & $19 \cdot 4$ & $9 \cdot 8$ & $25 \cdot 1$ & $10 \cdot 4$ & 0.04 \\
\hline PUFA (g) & $12 \cdot 1$ & $7 \cdot 7$ & $12 \cdot 7$ & $8 \cdot 1$ & $15 \cdot 9$ & $10 \cdot 7$ & $0 \cdot 14$ \\
\hline Cholesterol (mg) & $193 \cdot 9$ & $158 \cdot 7$ & $194 \cdot 5$ & $147 \cdot 7$ & $231 \cdot 3$ & $87 \cdot 6$ & 0.73 \\
\hline
\end{tabular}

${ }^{\mathrm{a}, \mathrm{b}}$ Mean values within a row with unlike superscript letters were significantly different (ANOVA with Hochberg correction). $P<0 \cdot 05$. tANOVA.

Table 3 Energy and macronutrient consumption according to socio-economic level (SEL) among children aged 9-12 years ( $n$ 1732), metropolitan region of Santiago, Chile, March-June 2007

\begin{tabular}{|c|c|c|c|c|c|c|c|c|}
\hline & \multicolumn{8}{|c|}{ SELt } \\
\hline & \multicolumn{2}{|c|}{$a+b$} & \multicolumn{2}{|c|}{$\mathrm{ca}$} & \multicolumn{2}{|c|}{$\mathrm{cb}$} & \multicolumn{2}{|c|}{$d+e$} \\
\hline & Mean & SD & Mean & SD & Mean & SD & Mean & SD \\
\hline Energy (kJ) & $8424^{a}$ & 2244 & $7615^{\mathrm{b}}$ & 2399 & $7817^{\mathrm{b}}$ & 2654 & $8357^{\mathrm{a}}$ & 3203 \\
\hline Protein (g) & $77 \cdot 5^{a}$ & $19 \cdot 4$ & $68 \cdot 3^{b}$ & $24 \cdot 1$ & $64 \cdot 4^{\mathrm{b}}$ & $23 \cdot 2$ & $65 \cdot 9^{\mathrm{b}}$ & $26 \cdot 7$ \\
\hline Carbohydrate (g) & $284 \cdot 9^{a, b}$ & $87 \cdot 9$ & $262 \cdot 7^{\mathrm{b}}$ & 86.9 & $278 \cdot 5^{b}$ & $95 \cdot 1$ & $304 \cdot 4^{a}$ & $118 \cdot 0$ \\
\hline Fibre $(\mathrm{g})$ & $17 \cdot 3$ & $8 \cdot 4$ & $17 \cdot 1$ & $11 \cdot 3$ & $17 \cdot 2$ & 9.9 & $17 \cdot 9$ & $9 \cdot 7$ \\
\hline Total fat $(\mathrm{g})$ & $63 \cdot 8^{a}$ & 23.9 & $56 \cdot 2^{b}$ & $24 \cdot 5$ & $56 \cdot 1^{\mathrm{b}}$ & $27 \cdot 7$ & $58 \cdot 3^{a, b}$ & $29 \cdot 9$ \\
\hline SFA $(g)$ & $20 \cdot 9$ & $10 \cdot 2$ & $19 \cdot 4$ & $9 \cdot 6$ & $19 \cdot 0$ & $9 \cdot 8$ & $19 \cdot 1$ & 0.3 \\
\hline MUFA (g) & $21 \cdot 3^{a}$ & $9 \cdot 0$ & $18 \cdot 6^{\mathrm{b}}$ & $9 \cdot 4$ & $18 \cdot 2^{\mathrm{b}}$ & $8 \cdot 7$ & $19 \cdot 2^{b}$ & $9 \cdot 9$ \\
\hline PUFA (g) & $14 \cdot 0^{a}$ & $6 \cdot 6$ & $11 \cdot 9^{b}$ & 6.9 & $11 \cdot 7^{\mathrm{b}}$ & $7 \cdot 6$ & $12 \cdot 5^{a, b}$ & $8 \cdot 8$ \\
\hline Cholesterol (mg) & $202 \cdot 7^{a, b}$ & $120 \cdot 9$ & $185 \cdot 4^{a, b}$ & $128 \cdot 8$ & $179 \cdot 9^{a}$ & $134 \cdot 8$ & $210 \cdot 5^{b}$ & $193 \cdot 5$ \\
\hline
\end{tabular}

ta $+\mathrm{b}$, very high and high; $c a$, middle-high; $\mathrm{cb}$, middle; $\mathrm{d}+\mathrm{e}$, middle-low and low.

${ }^{\mathrm{a}, \mathrm{b}}$ Mean values within a row with unlike superscript letters were significantly different (ANOVA with Hochberg correction): $P<0 \cdot 05$. 
Table 4 Food consumption ( $\mathrm{g} / \mathrm{d}$; except for sugared beverages, $\mathrm{ml} / \mathrm{d}$ ) according to socio-economic level (SEL) among children aged 9-12 years ( $n$ 1732), metropolitan region of Santiago, Chile, March-June 2007

\begin{tabular}{|c|c|c|c|c|c|c|c|c|c|}
\hline & \multicolumn{8}{|c|}{ SEL +} & \multirow[b]{3}{*}{$P \ddagger$} \\
\hline & \multicolumn{2}{|c|}{$a+b$} & \multicolumn{2}{|c|}{ ca } & \multicolumn{2}{|c|}{$\mathrm{cb}$} & \multicolumn{2}{|c|}{$d+e$} & \\
\hline & Mean & SD & Mean & SD & Mean & SD & Mean & SD & \\
\hline Cereals & 187 & 122 & 127 & 100 & 142 & 124 & 147 & 151 & 0.01 \\
\hline Bread & $88 \cdot 5$ & 74.9 & 136 & $91 \cdot 8$ & 174 & 113 & 214 & 134 & 0.01 \\
\hline Legumes & $5 \cdot 6$ & $18 \cdot 9$ & $10 \cdot 7$ & $29 \cdot 1$ & $12 \cdot 5$ & $32 \cdot 2$ & $10 \cdot 6$ & 28.9 & 0.05 \\
\hline Fruits & 155 & 164 & 149 & 158 & 123 & 152 & 118 & 147 & 0.01 \\
\hline Vegetables & $77 \cdot 6$ & $70 \cdot 7$ & $61 \cdot 6$ & $67 \cdot 3$ & $63 \cdot 0$ & $70 \cdot 6$ & $52 \cdot 9$ & $56 \cdot 9$ & 0.001 \\
\hline Red meat & $70 \cdot 0$ & $58 \cdot 8$ & $67 \cdot 3$ & $69 \cdot 3$ & $53 \cdot 7$ & $56 \cdot 6$ & $56 \cdot 3$ & $54 \cdot 8$ & 0.001 \\
\hline White meat & $51 \cdot 5$ & $60 \cdot 7$ & $29 \cdot 6$ & $51 \cdot 7$ & $25 \cdot 9$ & $50 \cdot 8$ & $25 \cdot 4$ & $55 \cdot 7$ & 0.001 \\
\hline Fish & $12 \cdot 3$ & $38 \cdot 3$ & $5 \cdot 6$ & $21 \cdot 2$ & $7 \cdot 5$ & $24 \cdot 3$ & $6 \cdot 7$ & $21 \cdot 9$ & 0.005 \\
\hline Dairy products & 417 & 238 & 433 & 268 & 359 & 285 & 282 & 253 & 0.01 \\
\hline Fats and oils & 38.5 & $30 \cdot 3$ & $31 \cdot 3$ & $33 \cdot 4$ & $29 \cdot 6$ & $29 \cdot 3$ & $30 \cdot 8$ & $35 \cdot 6$ & 0.01 \\
\hline Sugars & $16 \cdot 2$ & $27 \cdot 7$ & $14 \cdot 6$ & $18 \cdot 0$ & $17 \cdot 8$ & $20 \cdot 6$ & $21 \cdot 9$ & $17 \cdot 8$ & 0.001 \\
\hline Candy & $50 \cdot 5$ & $50 \cdot 6$ & $42 \cdot 7$ & $47 \cdot 6$ & $57 \cdot 4$ & $73 \cdot 1$ & $55 \cdot 9$ & $62 \cdot 2$ & 0.07 \\
\hline Sugared beverages & 395 & 309 & 336 & 249 & 351 & 288 & 383 & 311 & $0 \cdot 14$ \\
\hline
\end{tabular}

ta+b, very high and high; ca, middle-high; cb, middle; $d+e$, middle-low and low.

‡ANOVA.

Table 5 Adequacy of food consumption according to the recommendations of the Chilean Ministry of Health ${ }^{(22)}$ among boys aged 9-12 years ( $n$ 894), metropolitan region of Santiago, Chile, March-June 2007

\begin{tabular}{lcll}
\hline & Adequacy (\%) & Recommendation & Recommended frequency \\
\hline Cereals & 294 & 1 cup & $4-5$ times/week \\
Bread & $95 \cdot 0$ & 2 pieces & Daily \\
Legumes & $58 \cdot 5$ & 1 cup & 2 times/week \\
Fruits & $33 \cdot 3$ & 3 pieces & Daily \\
Vegetables & $50 \cdot 8$ & 2 portions & Daily \\
Red and white meats & 216 & 4 ounces & 2 times/week \\
Fish & $17 \cdot 7$ & 4 ounces & 2 times/week \\
Dairy products & $60 \cdot 2$ & 3 cups & Daily \\
Fats and oils & 166 & 4 tsp & Daily \\
Sugars & $79 \cdot 0$ & 5 tsp & Daily \\
\end{tabular}

Table 6 Adequacy of food consumption according to the recommendations of the Chilean Ministry of Health ${ }^{(22)}$ among girls aged 9-12 years ( $n$ 838), metropolitan region of Santiago, Chile, March-June 2007

\begin{tabular}{lcll}
\hline & Adequacy (\%) & Recommendation & Recommended frequency \\
\hline Cereals & 606 & $\frac{1}{2}$ cup & $4-5$ times/week \\
Bread & 106 & $1 \frac{1}{2}$ pieces & Daily \\
Legumes & $89 \cdot 0$ & $\frac{1}{2}$ cup & 2 times/week \\
Fruits & $38 \cdot 3$ & 3 pieces & Daily \\
Vegetables & $51 \cdot 5$ & 2 portions & Daily \\
Red and white meats & 237 & 4 ounces & 2 times/week \\
Fish & $41 \cdot 5$ & 4 ounces & 2 times/week \\
Dairy products & $58 \cdot 3$ & 3 cups & Daily \\
Fats and oils & 147 & 4 tsp & Daily \\
Sugars & $92 \cdot 0$ & 4 tsp & Daily \\
\hline
\end{tabular}

obesity than those with lower SEL ${ }^{(24)}$. This pattern has been observed in many developed countries, but in developing countries the opposite is true; that is, obesity and overweight are more frequent in high income groups $^{(25)}$. In Chile, an advanced developing country in terms of the nutrition transition, we find a pattern similar to the one observed in developed countries. This may be explained by the propensity of the population to follow an occidental pattern of living, with high income groups worrying more about physical appearance than the poorer groups, especially in women ${ }^{(26)}$.

Reported PA was very low in this population. Only $34.6 \%$ reported an acceptable level of PA while $65 \cdot 4 \%$ had sedentary behaviour. PA levels were better in higher income children $(60 \cdot 4 \%)$. These results coincide with those reported by Burrows et al. in a smaller group of children, who found that PA had a direct relationship with $\mathrm{SEL}^{(20)}$. One explanation for these results is that children 
in higher SEL groups have more secure facilities for PA, so they are less constrained by their parents to stay in a secure environment like home.

In the present study we used the ESOMAR questionnaire to assess SEL. This instrument asks only two questions: (i) the type of job and position of the breadwinner; and (ii) the highest level of schooling in the adults.

No relationship was observed between nutritional status and PA in our study. However, Gillis et al. showed that self-reported PA was inversely related to obesity ${ }^{(27)}$ and Kain et al. obtained similar results when they applied an endurance test in children (Navett test) ${ }^{(28)}$. A possible explanation for this discrepancy could be that Kain et al. measured endurance while we obtained our results by questionnaire.

Food intake in the present study was determined by a $24 \mathrm{~h}$ recall, which has been demonstrated to have a large intra-individual variation. Nevertheless, when applied to a large number of individuals, it gives a good estimation of food intake ${ }^{(29)}$.

The majority of foreign studies on obesity have focused on finding a characteristic eating pattern in children. Muñoz et al. applied a $24 \mathrm{~h}$ recall to 3307 US children aged 2-19 years and also collected two food registers from these children. The authors found that only $30 \%$ of them consumed the recommended amounts of fruits, cereals, meat and dairy and only $36 \%$ had an adequate intake of vegetables, while just $1 \%$ of the children fulfilled all recommendations ${ }^{(30)}$. Díez-Gañán et al. evaluated 1852 Spanish children from 5 to 12 years old, applying two $24 \mathrm{~h}$ recalls, and concluded that about $50 \%$ of the children did not fulfil the recommendations for fruits and vegetables ${ }^{(31)}$

Several studies in relatively small groups in Chile have shown an inadequate eating pattern in the population. Atalah et $a l^{(8)}$ and Yañez et $a l^{(32)}$ found similar results to ours in terms of consumption by applying an FFQ in a sample of children from low SEL. This has been confirmed recently by Olivares et $a l .{ }^{(9)}$. In a more recent study Olivares et al. measured food intake by means of an FFQ in 204 girls of medium-high SEL and 358 girls of high SEL ${ }^{(24)}$. They showed that girls from high SEL groups consumed more milk, and less bread, snacks and sugared beverages, which could explain in part the reduced prevalence of obesity in this group compared with girls from lower SEL groups.

The results presented here agree with studies performed in Chile and abroad, showing a reduced consumption of fruits and vegetables, legumes, fish and dairy products and a high consumption of cereals, red and white meat, and fats and oils. An interesting aspect of our study is the marked difference in food consumption according to SEL. Children in the high SEL group, who presented less obesity prevalence, reported a healthier consumption pattern, while low SEL children consumed more bread, sugar, legumes and showed a tendency to a higher intake of sugar and other caloric sweeteners.
The eating pattern found in the present study showed that boys had a higher consumption of energy and macronutrients than girls, most certainly due to the difference in size, as has been shown in other studies ${ }^{(33,34)}$

The differences observed in nutrient intake were reflected when we determined the total energy value of the diet. Children in high SEL groups consumed a higher proportion of energy from protein and fats (mainly monoand polyunsaturated) than low SEL children (protein $15 \cdot 4 \% v \cdot 13 \cdot 0 \%$; fat $28 \cdot 5 \% v \cdot 26 \cdot 6 \%$, respectively) and a lower proportion from carbohydrate $(56 \cdot 6 \%$ v. $60 \cdot 9 \%$, respectively), which has also been described in other countries in Latin America ${ }^{(35)}$. This pattern has a direct relationship with family income since the foods that provide protein and fat have a higher price, while those foods that are cheaper contain a higher proportion of carbohydrate. Actually, foods that contribute a high proportion of carbohydrate show a closer relationship with the development of obesity in infants and children ${ }^{(36-38)}$.

In the present study obese children reported less energy consumption than lean ones. This has also been reported by Fisher et al. ${ }^{(39)}$. These results could be associated with errors in the estimation of portion sizes, the use of inaccurate methods of measurements of food intake or false report of consumption. It also could be due to advice received by them to reduce energy intake. We used a $24 \mathrm{~h}$ recall survey applied by a trained nutritionist who interviewed all the children to minimize possible errors. Nevertheless, it is possible that obese children, consciously or unconsciously, may forget foods eaten between meals or consuming high-energy snacks.

Compared with FAO recommendations the intake of macronutrients was deficient except for protein. Although a $75 \%$ adequacy does not mean that the diet is necessarily deficient, fibre intake was only about half of the recommended amount.

The adequate intake of micronutrients has been given importance in recent years in developing countries since a high consumption of energy does not guarantee an appropriate intake of micronutrients ${ }^{(40-42)}$. There are very few studies in Chile that have looked at micronutrient intake in children. Actually, international studies are also scarce. Using a $24 \mathrm{~h}$ recall survey and two food registers in 150 Swiss children aged 6-14 years, Aeberli et al. found a deficient intake (25\% adequacy) of vitamin $\mathrm{D}^{(33)}$. On the other hand, Muñoz et al. used the same methodology in 3307 North American children aged 2-19 years and found that only 1\% had adequate food consumption ${ }^{(30)}$. In Colombia, Gamboa et al. reported a low intake (50\% adequacy) of Ca and vitamin $B_{6}$ in 258 schoolchildren of low SEL using a $24 \mathrm{~h} \mathrm{recall}^{(35)}$. In our study the adequacy of micronutrients was good, except in the case of Ca, K, biotin, vitamin A and vitamin D in both sexes. The low consumption of $\mathrm{Ca}$ reported here has also been observed in other studies in Chile ${ }^{(32)}$.

Consumption of micronutrients according to SEL showed a higher intake of $\mathrm{Ca}, \mathrm{P}, \mathrm{K}$ and $\mathrm{Zn}$ in the high SEL 
$(\mathrm{a}+\mathrm{b})$ children, while children from the lowest SEL groups $(\mathrm{d}+\mathrm{e})$ showed a higher intake of $\mathrm{Fe}$, Se and $\mathrm{Na}$. The high SEL groups showed a higher intake of vitamins A, C, D, E, B $6, B_{12}$ and biotin while lower SEL children had a higher intake of thiamin and folate. These differences can be explained by a different pattern of consumption according to SEL. Bread is a major staple in low SEL, and by law it is fortified with thiamin, riboflavin, niacin, Fe and folic acid.

School should be a preferred site to impart nutrition education and increase PA in children. Nevertheless, these efforts are impaired by the neglect of physical education classes in favour of other subjects considered more important by teachers like maths or history, and by the presence of kiosks which tend to offer high-fat and high-sugar snacks and beverages. Although the Chilean Ministry of Education is addressing the problem to a certain extent, it is necessary to commit more resources to achieve this goal.

The limitations of the study are based on having realized only one $24 \mathrm{~h}$ recall in the children and measuring PA by questionnaire, both necessary due to the resources available. Another limitation is that Tanner stage was not evaluated in children, which could explain to some extent the similar results between boys and girls.

In conclusion, our study shows that on the average a high prevalence of overweight and obesity is present in Chilean schoolchildren aged 9-12 years. This is produced by a combination of reduced PA and inadequate diet. Prevalence of obesity was higher in children from low SEL, probably due to a higher consumption of carbohydrate. Although the diet seemed to be adequate in terms of macro- and micronutrients except for fibre, there was a low consumption of fruits and vegetables, fruits and dairy products.

\section{Acknowledgements}

The study was funded by the International Life Sciences Institute (ILSI), South Andean. There is no conflict of interest. Y.L. was involved in data collection, data interpretation, manuscript preparation and literature search. O.C. was involved in data collection, data interpretation and manuscript preparation. V.E. was general coordinator of the study. L.V. performed the statistical analysis. J.R. did the study design, was involved in data interpretation and manuscript preparation, and obtained funding. The authors would like to thank Marisol Caceres for her help in data input.

\section{References}

1. Ogden L, Flegal K, Carroll M et al. (2002) Prevalence and trends in overweight among US children and adolescents, 1999-2000. JAMA 288, 1728-1732.
2. Costa R, Cintra I, Fisberg M et al. (2006) Prevalencia de sobrepeso e obesidade em escolares da cidade de Santos SP. Arq Bras Endocrinol Metabol 50, 60-67.

3. Ministry of Health, Chile (2009) Basic Health Indicators 2007. http://deis.minsal.cl/deis/indicadores/indi2007.pdf (accessed June 2009).

4. Must A, Jacques P, Dallai G et al. (1992) Long-term morbidity and mortality of overweight adolescents. $N$ Engl $J$ Med 327, 1350-1355.

5. Interdepartmental Committee of Nutrition for National Defence (1961) Nutrition Survey, Chile, March-June 1960. A report by the Interdepartmental Committee of Nutrition for National Defence. Santiago: ICNND.

6. Chilean National Organization for School Help and Fellowships, JUNAEB (2008) Prevalence of obesity in first grade children by region, 2008. http://www.sistemas.junaeb.cl/ estadosnutricionales_2007/tablaobesidadregion (accessed December 2008)

7. Ministry of Health, National Statistics Institute, Chile (2004) Encuesta Nacional de Salud (ENS) 2003. Santiago: Ministerio de Salud.

8. Atalah E, Urteaga C, Rebolledo A et al. (1999) Patrones alimentarios y de actividad física en escolares de la Región de Aysén. Rev Chil Pediatr 70, 483-490.

9. Olivares S, Kain J, Lera L et al. (2004) Nutritional status, food consumption and physical activity among Chilean school children: a descriptive study. Eur J Clin Nutr 58, 1278-1285.

10. Chilean National Organization for School Help and Fellowships, JUNAEB (2008) School Vulnerability Index (SVI). http://www.junaeb.cl/alimentacion/index.htm (accessed May 2007).

11. Centers for Disease Control and Prevention/National Center for Health Statistics (2000) CDC growth charts: United States. http://www.cdc.gov/growthchart (accessed September 2008).

12. Slaughter $\mathrm{MH}$, Lohman TG, Boileau RA et al. (1988) Skinfolds equations for estimation of body fatness in children and youth. Hum Biol 60, 709-723.

13. Rodríguez G, Moreno LA, Blay MG et al. (2005) The AVENA-Zaragoza Study Group. Body fat measurement in adolescents: comparison of skinfold thickness equations with dual-energy X-ray absorptiometry. Eur J Clin Nutr 59, $1158-1166$.

14. Castillo O, Rozowski J, Muñoz X et al. (1998) Ingesta de nutrientes en vegetarianos chilenos. Rev Chil Nutr 25, 39-44.

15. Food and Agriculture Organization of the United Nations/ World Health Organization/United Nations University (2004) Human Energy Requirements. Report of a Joint FAO/WHO/UNU Expert Consultation, Rome, 17-24 October 2001. FAO Food and Nutrition Technical Report Series no. 1. Rome: FAO.

16. Food and Nutrition Board, Institute of Medicine (1997) Dietary Reference Intakes for Calcium, Phosphorus, Magnesium, Vitamin $D$, and Fluoride. Washington, DC: National Academy Press.

17. Food and Nutrition Board, Institute of Medicine (1998) Dietary Reference Intakes: Thiamin, Riboflavin, Niacin, Vitamin $B_{6}$, Folate, Vitamin $B_{12}$, Pantothenic Acid, Biotin, and Choline. Washington, DC: National Academy Press.

18. Food and Nutrition Board, Institute of Medicine (2001) Dietary Reference Intakes: Vitamin A, Vitamin K, Arsenic, Boron, Chromium, Copper, Iodine, Iron, Manganese, Molybdenum, Nickel, Silicon, Vanadium, and Zinc. Washington, DC: National Academy Press.

19. Food and Nutrition Board, Institute of Medicine (2000) Dietary Reference Intakes: Vitamin C, Vitamin E, Selenium, and Carotenoids. Washington, DC: National Academy Press. 
20. Burrows R, Diaz E, Sciaraffia V et al. (2008) Hábitos de ingesta y actividad física en escolares, según tipo de establecimiento al que asisten. Rev Med Chile 136, 53-63.

21. European Society for Opinion and Marketing Research (1997) A System of International Socio-economic Classification of Respondents to Survey Research. Amsterdam: ESOMAR.

22. Jury G, Urteaga C \& Taibo M (1997) Porciones de intercambio y composición química de los alimentos de la pirámide alimentaria chilena. Santiago: INTA, Centro de Nutrición Humana, Facultad de Medicina, University of Chile.

23. Lioret S, Touvier M, Lafay L et al. (2008) Dietary and physical activity patterns in French children are related to overweight and socioeconomic status. J Nutr 138, 101-107.

24. Olivares S, Bustos N \& Lera L (2007) Estado nutricional, consumo de alimentos y actividad física en escolares mujeres de diferente nivel socioeconómico de Santiago de Chile. Rev Med Chil 135, 71-78.

25. Groeneveld I, Solomons N, Doak C et al. (2007) Nutritional status of urban school children of high and low socioeconomic status in Quetzaltenango, Guatemala. Rev Panam Salud Publica 22, 169-177.

26. Lera L, Olivares S, Leyton B et al. (2006) Patrones alimentarios y su relación con sobrepeso y obesidad en niñas chilenas de nivel socioeconómico medio alto. Arch Latinoam Nutr 56, 165-170.

27. Gillis L, Kennedy L, Gillis A et al. (2002) Relationship between juvenile obesity, dietary energy and fat intake and physical activity. Int J Obes Relat Metab Disord 26, 458-463.

28. Kain J, Olivares S, Romo M et al. (2004) Nutritional status and aerobic capacity among children attending public elementary schools in Chile. Rev Med Chil 132, 1395-1402.

29. Serra Majem L \& Ribas B (1995) 24-hour recall. In Nutrición y Salud Pública: Métodos, Bases Científicas y Aplicaciones, pp. 113-119 [L Serra Majem, J Aranceta Bartrina, J Mataix Verdú et al., editors]. Barcelona: Masson.

30. Muñoz K, Krebs-Smith M, Ballard-Barbash R et al. (1997) Food intakes of US children and adolescents compared with recommendations. Pediatrics 100, 323-329.
31. Díez-Gañán L, Galan I, León CM et al. (2007) Ingesta de alimentos, energía y nutrientes en la población de 5 a 12 años de la comunidad de Madrid, resultados de la encuesta de nutrición infantil 2001-2002. Rev Esp Salud Publica 81, 543-558

32. Yáñez R, Olivares S, Torres I et al. (2001) Consumo de alimentos de escolares Chilenos. Su relación con las guías y la pirámide alimentaria. Rev Chil Nutr 28, 422-428.

33. Aeberli I, Kaspar M \& Zimmermann M (2007) Dietary intake and physical activity of normal weight and overweight 6 to 14 year old Swiss children. Swiss Med Wkly 137, 424-430.

34. Crespo C, Smit E \& Troiano R (2001) Television watching, energy intake, and obesity in US children. Arch Pediatr Adolesc Med 155, 360-365.

35. Gamboa E, López N, Vera L et al. (2007) Displaced and local children's alimentary patterns and nutritional state in Piedecuesta, Colombia. Rev Salud Publica 9, 129-139.

36. Malik V, Schulze M \& Hu F (2006) Intake of sugarsweetened beverages and weight gain: a systematic review. Am J Clin Nutr 84, 274-288.

37. Van Dam R \& Seidell J (2007) Carbohydrate intake and obesity. Eur J Clin Nutr 61, Suppl. 1, S75-S99.

38. Stefanik P, Heald F \& Mayer J (1959) Caloric intake in relation to energy output of obese and non obese adolescent boys. Am J Clin Nutr 7, 55-62.

39. Fisher J, Johnson R, Lindquist C et al. (2000) Influence of body composition on the accuracy of reported energy intake in children. Obes Res 8, 597-603.

40. Troiano RP, Briefel RR, Carroll MD et al. (2000) Energy and fat intake of children and adolescents in the United States: data from the Nutritional Health and Nutrition Examination Surveys. Am J Clin Nutr 72, 5 Suppl., 1343S-1353S.

41. Devaney B, Ziegler P, Pac S et al. (2004) Nutrient intakes of infants and toddlers. J Am Diet Assoc 104, 1 Suppl. 1, S14-S21.

42. Troiano R \& Flegal K (1998) Overweight children and adolescents: description, epidemiology and demographics. Pediatrics 101, 497-504. 